\title{
ESTIMATING THE KNOWLEDGE-CAPITAL MODEL OF THE MULTINATIONAL ENTERPRISE
}

\author{
David L. Carr \\ James R. Markusen \\ Keith E. Maskus \\ Working Paper 6773 \\ http://www.nber.org/papers/w6773

\section{NATIONAL BUREAU OF ECONOMIC RESEARCH \\ 1050 Massachusetts Avenue \\ Cambridge, MA 02138 \\ October 1998}

Markusen's portion of this research was funded by a grant from the National Science Foundation through the NBER. The views expressed here are those of the author and do not reflect those of the National Bureau of Economic Research.

(C) 1998 by David L. Carr, James R. Markusen, and Keith E. Maskus. All rights reserved. Short sections of text, not to exceed two paragraphs, may be quoted without explicit permission provided that full credit, including $\mathbb{C}$ notice, is given to the source. 
Estimating the Knowledge-Capital Model

of the Multinational Enterprise

David L. Carr, James R. Markusen,

and Keith E. Maskus

NBER Working Paper No. 6773

October 1998

JEL No. F12, F23

\section{ABSTRACT}

What we term the "knowledge-capital model" of the multinational firm includes three principal assumptions. First, services of knowledge-based and knowledge-generating activities, such as $R \& D$, can be geographically separated from production and supplied to production facilities at low cost. Second, these knowledge-intensive activities are skilled-labor intensive relative to production. These characteristics give rise to vertical multinationals, which fragment production and locate activities according to factor prices and market size. Third, knowledgebased services have a (partial) joint-input characteristic, in that they can be supplied to additional production facilities at low cost. This characteristic gives rise to horizontal multinationals, which produce the same goods or services in multiple locations. In this paper, we note how this model predicts relationships between affiliate sales and country characteristics. We then subject these predictions to empirical tests.

David L. Carr

Department of Economics

University of Colorado

Boulder, CO 80309-0256

David.Carr@colorado.edu

James R. Markusen

Department of Economics University of Colorado

Boulder, CO 80309-0256

and NBER

James.Markusen@colorado.edu

Keith E. Maskus

Department of Economics

University of Colorado

Boulder, CO 80309-0256

Keith.Maskus@colorado.edu 
The industrial-organization approach to international trade ("new trade theory") has incorporated features of increasing returns to scale, imperfect competition, and product differentiation into traditional general-equilibrium trade models. These new models offer rich predictions about the direction and volume of trade between two countries as functions of industry characteristics (factor intensities, scale economies, product differentiation) interacting with country characteristics (relative size differences, relative endowment differences, and trade costs).

However, an awkward empirical problem is that most of the firms and industries motivated by the IO approach to trade are multinational firms, while most of the theory has been about single-plant national firms. More recent theoretical developments have incorporated multinational firms, which maintain facilities in more than one country. These multinationals are often broken down into "horizontal" firms, which produce the same goods and services in multiple countries, and "vertical" firms, which geographically fragment production by stages. An early example of a model with vertical multinationals is in Helpman (1984) while an early model of horizontal multinationals is in Markusen (1984).

Subsequent theoretical work has focused on horizontal firms because they seem to be more prevalent in the world. Examples include Horstmann and Markusen (1987, 1992), Brainard (1993a), and Markusen and Venables (1996, 1997, 1998). These models have since been subjected to empirical tests, especially by Brainard (1993b, 1997) and Ekholm (1995, 1997a,b, 1998). Results give good support to the theoretical predictions of the "horizontal" models: multinational activity should be concentrated among countries that are relatively similar in both size and in relative endowments (or per capita incomes). 
Theoretical models combining both horizontal and vertical motives for direct investment are analytically difficult. Helpman's original model of vertical multinationals relied on the assumption of no trade costs, but in that case there is no motive for horizontal multinationals (given plant-level scale economies). For analytical tractability, the early models of horizontal firms assumed that different activities (e.g., headquarters services and plant production) use factors in the same proportion or that there is only one factor of production. However, this permits no factor-price motive for vertical fragmentation across countries.

Two recent models exist in which both vertical and horizontal firms can arise endogenously due to the simultaneous existence of trade costs and different factor intensities across industries. Analytical difficulties, however, imply that most results are derived from numerical simulations (Markusen (1997), Markusen, et al (1996)). These simulations generate a number of testable implications, relating direct investment to country characteristics.

The purpose of this paper is therefore to take the theoretical predictions of recent theory and subject them to econometric test. We begin by reviewing this newer theory and discussing its theoretical predictions. The theory explains the volume of production of foreign affiliates of one country's firms in another country as a function of the characteristics of both countries. For example, production by affiliates of the parent-country firms in the host country will be high if the countries are similar in size and trade costs are high, in which case affiliates are horizontal. Production will also be high if the parent country is small and skilled-labor abundant relative to the host nation and trade costs are low, in which case affiliates are vertical.

Next we translate these predictions into a tractable empirical specification. The theory predicts that many relationships are interactive or non-linear. For one example, an increase in 
trade costs will increase production by affiliates if the countries are similar (direct investment is horizontal) but may decrease investment if the countries are different in relative endowments (direct investment is vertical). For another, the effect of an increase in the parent country's GNP level on production by affiliates of its firms abroad is non-monotonic. It increases if the parent country is small but decreases if the size of the parent country exceeds the size of the host country. Further, the effect of an increase in the parent country relative endowment of skilled labor on production by its firms' affiliates are positive and large if trade costs are small (vertical investment is encouraged) but are smaller if trade costs are large. Finally, the volume of affiliate production is highest when the parent country is both skilled-labor abundant and small relative to the host country.

Results of our estimations are closely consistent with the theory. The volume of affiliate sales follows the theoretical predictions based on characteristics of both parent and host countries. Both vertical and horizontal investments are important and related to country characteristics as the model predicts.

\section{The Theoretical Model}

We now present a theoretical model drawn from Markusen (1997) and Markusen, Venables, Konan and Zhang (1996). First, we present a broad outline of the model, and then discuss crucial assumptions about the level and composition of fixed costs. The model assumes the existence of two homogeneous goods ( $\mathrm{X}$ and $\mathrm{Y}$ ), two countries ( $\mathrm{h}$ and $\mathrm{f}$ ), and two homogeneous factors, unskilled labor (L) and skilled labor (S), which are internationally immobile. Good $\mathrm{Y}$ is labor-intensive and produced under constant returns to scale in a 
competitive industry. Good $\mathrm{X}$ is skilled-labor-intensive overall, exhibits increasing returns to scale, and is subject to Cournot competition with free entry and exit. In this good headquarters services and plant facilities may be geographically separated and a firm may have plants in one or both countries.

With this structure, there are six firm types, with free entry and exit into and out of firm types. Regime denotes a set of firm types active in equilibrium. Firm types are as follows:

Type $m_{h}-\quad$ horizontal multinationals that maintain plants in both countries with headquarters located in country $\mathrm{h}$.

Type $m_{f}-\quad$ horizontal multinationals that maintain plants in both countries with headquarters located in country f.

Type $n_{h}-\quad$ national firms that maintain a single plant and headquarters in country $h$; they may or may not export to country f.

Type $\mathrm{n}_{\mathrm{f}}-\quad$ national firms that maintain a single plant and headquarters in country $\mathrm{f}$; they may or may not export to country $h$.

Type $\mathrm{v}_{\mathrm{h}}$ - vertical multinationals that maintain a single plant in country $\mathrm{f}$ and headquarters in country h; they may or may not export to country h.

Type $\mathrm{v}_{\mathrm{f}}$ - vertical multinationals that maintain a single plant in country $\mathrm{h}$ and headquarters in country f; they may or may not export to country f.

In the model, national markets for goods are segmented and transport costs use unskilled labor. Type-v firms incur a small cost penalty relative to type-n firms as a "transactions cost" of geographically separating plant and headquarters.

Assumptions about the size and composition of fixed costs are crucial to the predictions of 
the model. ${ }^{1}$ First, we assume the existence of multi-plant economies of scale (relevant to type-m firms) due to a joint-input property of knowledge capital. Headquarters service (blueprints, manuals, formulas, procedures, etc.) can be supplied to additional plants at low marginal cost. Thus, in good $\mathrm{X}$ the total fixed costs of headquarters and two plants is less than the double the total fixed costs of a single-plant firm (the joint-input property of knowledge capital).

Second, it is assumed that headquarters services are more skilled-labor-intensive than production. Somewhat more controversial is our assumption that plant-level production is more skilled-labor-intensive than the composite rest of the economy. Thus, we stipulate that the ranking of skilled-labor intensity of activities is [headquarters only] > [integrated X] > [plant only $]>[\mathrm{Y}]$.

Finally, we assume that two-plant type-m firms are more skilled-labor-intensive than either type-n or type-v firms. The hypothesis is that type-m firms use additional skilled labor both at home and in the host country in managing and operating the second plant. Type-n and type- $\mathrm{V}$ firms use additional unskilled labor in transport costs in serving the foreign market. ${ }^{2}$ Thus, the skilled-labor- intensity ranking of firm types is [type-m firms] > [type-v and type-n firms] .

The full set of equations and inequalities characterizing equilibrium in the model is given in Markusen (1997) and in Markusen, et al (1996) and we will not repeat that exercise here. In the next section, we link the assumptions about technology to country characteristics in order to

1 The following assumptions draw empirical support from a large number of studies, including Aitken et al (1995), Blomstrom et al (1997), Caves (1996), Ekholm (1995, 1997a, 1997b), Feenstra and Hanson (1997), Lipsey et al (1995), Slaughter (1999), and UNCTAD (1993). Data drawn from some of these sources are presented in Markusen (1997).

${ }^{2}$ This particular assumption does not play a significant role in this paper but does lead to interesting factor-market effects from investment liberalization, such as the relative wage of skilled labor can rise in both countries (Markusen, 1997). 
generate predictions about multinational actively as a function of those country characteristics.

\section{3. $\quad$ Active Firm Types and Country Characteristics}

We explain country characteristics that favor various firm types producing or maintaining headquarters in country h. Analogous comments apply to firms in country f. Consider first factors that favor national firms headquartered in country $\mathrm{H}$ and also producing there. Assumptions of the model developed above suggest that type $\mathrm{n}_{\mathrm{h}}$ firms will be the dominant type active in $\mathrm{h}$ if: (1) $\mathrm{h}$ is both large and skilled-labor abundant; (2) $\mathrm{h}$ and $\mathrm{f}$ are similar in size and relative endowments and transport costs are low (type $\mathrm{n}_{\mathrm{f}}$ will sell in $\mathrm{h}$ ); or (3) foreign investment barriers in $\mathrm{f}$ are high (type $\mathrm{n}_{\mathrm{f}}$ may sell in $\left.\mathrm{h}\right)^{3}$

Country $\mathrm{h}$ being large supports production there while skilled-labor abundance favors locating headquarters in $\mathrm{h}$ as well. Thus, an integrated type- $\mathrm{n}_{\mathrm{h}}$ firm has a cost advantage over a type- $v_{h}$ or $v_{f}$ firm. A type- $n_{h}$ firm also has an advantage over a type- $m_{h}$ firm, which must locate costly capacity in the small $\mathrm{f}$ market unless trade costs are high. Type-n firms should also be dominant when the countries are similar and trade costs are small. If countries are perfectly symmetric, for example, there is no motive for type-v firms given the assumption of a small cost penalty to separating activities. Small trade costs favor type-n firms over two-plant type-m firms.

Type- $m_{h}$ firms will be the dominant type active in country $h$ if the nations are similar in size and relative endowments and transport costs are high (type $\mathrm{m}_{\mathrm{f}}$ will also produce in $\mathrm{h}$ ). Thus, horizontal multinationals firms should be associated with similarities between countries in both size and in relative factor endowments. The intuition behind is that if countries are dissimilar in

\footnotetext{
${ }^{3}$ The word "dominant" means that the number of firms of this type is larger than the number of firms of any other
} 
either size or relative endowments, one country will be "favored" as a site of production and/or headquarters. For example, if the countries are similar in relative endowments but of different sizes, then national firms located in the large country will be favored because they avoid costly capacity in the smaller market. If the countries are different in relative endowments but of similar size, then there is an incentive to concentrate headquarters in the skilled-labor-abundant country and production in the skilled-labor-scarce country. Thus vertical firms headquartered in the skilled-labor-abundant countries are favored unless trade costs are high.

From this analysis two predictions about vertical multinationals follow directly. First, type- $\mathrm{v}_{\mathrm{h}}$ firms will be dominant in $\mathrm{h}$ if country $\mathrm{h}$ is small, skilled-labor abundant, and transport costs are not excessive. Second, type- $\mathrm{v}_{\mathrm{f}}$ firms will be dominant in h if country $\mathrm{h}$ is large, skilledlabor scarce, and transport costs are not excessive.

\section{4. $\quad$ Simulation Results}

Data exist on the volume of production in host countries by affiliates of firms in parent countries, but not on the number of firms of various types. Accordingly, we need to develop predictions about affiliate production, rather than the numbers of firms of various types. In this section, we solve the model numerically in order to generate such predictions on the relationship between affiliate sales and country characteristics. ${ }^{4}$

A preliminary issue is to define "affiliate production" in the model in a way that relates

type in the associated equilibrium.

${ }^{4}$ The full model, consisting of 41 non-linear inequalities, is solved as a complementarity problem using Rutherford's (1995) solver MPS/GE, a subsystem of GAMS. See Markusen (1997) and Markusen, et al (1996) for 
sensibly to data on affiliate sales. Parents and affiliates in the data are essentially defined in terms of ownership location. Thus, in our model we assume that the country in which a firm's headquarters are located is the parent country. Given that assumption, the production of affiliates of country-h firms in country $\mathrm{f}$ is the output of plants in country $\mathrm{f}$ "owned" by type- $\mathrm{m}_{\mathrm{h}}$ and type- $\mathrm{V}_{\mathrm{h}}$ firms. Similarly, the volume of production by country-h affiliates of country $f$ firms is the production in country-h plants owned by type- $\mathrm{m}_{\mathrm{f}}$ and type- $\mathrm{v}_{\mathrm{f}}$ firms.

Simulation results are demonstrated with a series of world Edgeworth box diagrams in Figures 1-5, with the total world endowment of skilled labor on the "Y" axis and the total world endowment of unskilled labor on the " $\mathrm{X}$ " axis. The origin for country $\mathrm{h}$ is at the southwest (SW) corner of the box and the origin for country $f$ is at the northeast (NE) corner. Along the SW-NE diagonal, the countries have identical relative endowments but differ in size. The locus along which the countries have equal incomes but differ in relative endowments is steeper than the diagonal and is not quite linear. The approximate locus along which the countries have equal incomes is given by the line drawn on the floor of the box in Figure 1 . Country $\mathrm{h}$ is smaller than country f to the left of this locus and is larger to the right.

Figure 1 shows simulation outcomes at high trade costs, with affiliate production being the sum of the outputs of both countries' affiliated plants. Note that Figure 1 contains a classic saddle. Affiliate sales are at a minimum when the two countries are similar in relative endowments but different in size, in which case national firms headquartered in the large country dominate $\mathrm{X}$ production. Moving along the SW-NE diagonal (relative endowments identical), total affiliate sales reach a maximum at the mid-point where the countries are identical. At this 
point, all firms are type-m and exactly half of all world production of $\mathrm{X}$ is affiliate production. The other half is output of the domestic plants of type-m firms.

A somewhat surprising result in Figure 1 is that total affiliate production is highest when one country is both small (but not too small!) and skilled-labor abundant. In such a situation, type-v firms located in that country are the dominant firm-type. Note that if only type-v firms were active in equilibrium, then all of the world production of $\mathrm{X}$ is affiliate sales. Conversely, affiliate activity is lowest when the skilled-labor-abundant country is large, in which case all production of $\mathrm{X}$ is by national firms headquartered in that country.

The non-linearities in Figure 1 present a challenge for testing. For example, the effect of differences in country size on affiliate sales depends on whether the countries are similar in relative endowments and, if they are different in size, on whether the small country is the skilledlabor abundant country.

Figure 2 plots only the production by h-owned plants in country f. Here again, we see the inverted u-shaped curve of production along the SW-NE diagonal, but affiliate production is highest when country $\mathrm{h}$ is moderately small and highly skilled-labor abundant. The latter situation is especially reminiscent of Sweden, Switzerland, and The Netherlands, which are small, skilledlabor-abundant countries and important parent countries for multinationals.

Figures 3 through 5 present results concerning the effects of trade costs, assumed here to be symmetric in both directions, on production by h-owned plants in country f. On the vertical axes of these diagrams is affiliate sales with $25 \%$ trade costs minus affiliate sales with $5 \%$ trade costs. Again, we see that the results are highly non-linear. Figure 3 demonstrates that higher trade costs increase total affiliate sales if the countries are relatively similar in size and in relative 
endowments. Similarity favors horizontal multinationals and, as we noted earlier, horizontal production is encouraged by higher trade costs. Higher trade costs, however, reduce total affiliate sales when there is a moderate difference in relative endowments and the skilled-laborabundant country is somewhat smaller. These are regions with type-v firms headquartered in the skilled-labor-abundant country and with a correspondingly large volume of X trade. Higher trade costs "bring some plants back home" to the skilled-labor abundant country. In the NW region of negative change in Figure 3, for example, higher trade costs lead to a substitution of some type- $\mathrm{n}_{\mathrm{h}}$ firms for some type- $\mathrm{v}_{\mathrm{h}}$ firms, thereby reducing the volume of affiliate production. Parenthetically, these are regions in which trade and affiliate sales are complements, in that higher trade costs reduce both.

The results in Figure 3 are derived for an equal increase in trade costs in both directions. This is not a very useful experiment to take to the data. Fortunately, the results break down nicely into the effects of trade costs in the host country $\mathrm{f}$ and the trade costs to enter the parent country h. These results are shown in Figures 4 and 5. Figure 4 shows that one effect of higher trade costs in country $f$ is to increase production of affiliates of country $h$ firms in $f$ if the countries are relatively similar (horizontal investments). Figure 5 shows that the effect of increased trade costs into the parent-country $\mathrm{h}$ is to discourage vertical investments in which the output of the plant in country $\mathrm{f}$ is shipped back to country $\mathrm{h}$. This impact occurs when $\mathrm{h}$ is relatively small and skilled-labor abundant.

These various results lead us to specify the following central equation for estimation purposes: 


$$
\begin{aligned}
& \text { RSALES = B0 + B1(SUMGDP })+ \text { B2(GDPDIFSQ })+ \text { B3(SKDIFF })+ \\
& \mathrm{B} 4(\text { GDPDIFF*SKDIFF })+\mathrm{B} 5(\mathrm{INVCJ})+\mathrm{B} 6(\mathrm{TCJ})+\mathrm{B} 7(\mathrm{TCJ} * \mathrm{SKDIFSQ})+\mathrm{B} 8(\mathrm{TCI})+ \\
& \mathrm{u}
\end{aligned}
$$

Here, RSALES is the real volume of production (sales) by affiliates in country $\mathrm{j}$ of parents in country i. The variable SUMGDP is the sum of real GDP in the two countries, GDPDIFF is the difference between GDP in country $\mathrm{i}$ and GDP in country $\mathrm{j}$, and GDPDIFSQ is the squared difference in GDP levels. The variable SKDIFF is a measure of skilled labor abundance in country i relative to country $\mathrm{j}$, and SKDIFSQ is the squared difference in this measure.

The dependent variable is the real volume of production (sales to all markets) by affiliates in country $\mathrm{j}$ of parents in country $\mathrm{i}$ (RSALES). The first independent variable is SUMGDP, the sum of real GDP in both countries, which we expect to have a positive sign. Indeed, a stronger hypothesis is that the elasticity of affiliate sales with respect to SUMGDP is greater than one. The second variable is GDPDIFSQ, the squared difference in real GDP. We expect its coefficient to be negative because our theory says that RSALES has an inverted u-shaped relationship to differences in country size, with a maximum at zero differences. This is demonstrated along the SW-NE diagonal in Figure 1.

The third variable is SKDIFF, which is a measure of skilled-labor abundance in the parent country relative to the host country. We expect its coefficient to be positive because firms tend to be headquartered in the skilled-labor-abundant country. A fourth variable is the interaction between differences in skill endowments and economic size. We anticipate its sign to be negative for reasons shown in Figure 2. In particular, affiliates sales are highest when the country is small and skilled-labor abundant. 
The fifth and sixth variables, INVCJ and TCJ, respectively measure costs of investing in, and exporting to, the host country. We expect the investment-cost coefficient to be negative and the trade-cost coefficient to be positive. The interaction term between trade costs and squared endowment differences is designed to capture the fact that trade costs may encourage horizontal investment but not vertical investment and that horizontal investment is most important when relative endowments are similar. The coefficient should therefore be negative, weakening the direct effect of host-country trade costs. The results in Figure 4, however, show that the effect of the host-country trade costs is not symmetric around the SW-NE diagonal and is actually highest when the parent country is moderately skilled-labor abundant. Thus, this is not a theoretically sharp hypothesis and, indeed, empirical support for this term is weak, as we shall see.

The final regressor is TCI, or trade costs in exporting to the parent country. The coefficient should be negative because trade costs diminish the incentive to locate plants abroad for shipment back to the home market, as shown in Figure 5. Figure 5 also indicates that TCI should be interacted with SKDIFF, but the resulting variable is highly collinear with SKDIFF because skilled-labor-scarce countries have high trade-cost indexes. ${ }^{5}$ Thus, we exclude this interaction variable in the estimates provided here. Finally, in some versions of the econometric model we add geographic distance, DIST, as an independent variable. The sign of this variable is ambiguous in theory, because distance is an element in both export costs and investment and monitoring costs. We specify the regression as linear in levels, with quadratic and interaction terms included.

We may consider the sense of the interactive terms in more detail by writing the implied

\footnotetext{
${ }^{5}$ The partial correlation coefficient between them is -0.96 .
} 
partial derivatives from equation (1). The derivative of RSALES with respect to TCJ has two terms:

$$
\frac{\partial R S A L E S}{\partial T C J}=B 6+B 7(\operatorname{SKDIFSQ})
$$

Because B6 is greater than zero, this derivative is expected to be positive when relative endowments are similar, reflecting the fact that host-country trade costs encourage horizontal direct investment. But it should be smaller when relative endowments differ, in which case horizontal investment is less important. This implies that the expected sign of B7 is negative.

The derivative of RSALES with respect to GDPDIFF has two terms:

$\frac{\partial R S A L E S}{\partial G D P D I F F}=B 2(2 * G D P D I F F)+B 4(S K D I F F)$

The relationship should be an inverted $U$ as noted above, reaching a maximum when the countries are similar in relative endowments, which is captured by the first term and the negative coefficient B2. However, our theory predicts that investment could fall with increases in country i's size if country $i$ is skilled-labor abundant, which is reflected in the second term and the expected negative sign on B4.

Finally, the derivative of RSALES with respect to SKDIFF has three terms:

$$
\frac{\partial R S A L E S}{\partial S K D I F F}=B 3+B 4(G D P D I F F)+B 7(2 * T C J * S K D I F F)
$$

The first term is a direct effect that should be positive, capturing both vertical direct investment and headquarters of horizontal firms. The direct effect is weakened as the parent country gets larger, since vertical firms are replaced by national firms, headquartered in the parent nation, that 
serve the destination country by exports. This effect is also weakened if SKDIFF takes on a large value (see figure 2). The coefficients B4 and B7 both appear twice in the three derivatives and are predicted to be negative in each case (although the theoretical case for B7 is not particularly strong, as noted earlier).

\section{Data Sources and Estimation Results}

Data for the estimation form a panel of cross-country observations over the period 1986-

94. We take real sales volume of non-bank manufacturing affiliates in each country to indicate production activity. The U.S. Department of Commerce provides annual data on sales of foreign affiliates of American parent firms and on sales of U.S. affiliates of foreign parent firms. Thus, for each year the United States serves as both the headquarters country for its firms producing abroad and the affiliate country for foreign firms producing there. There are 36 countries in addition to the US for which we have at least one year of complete data. Annual sales values abroad are converted into millions of 1990 U.S. dollars using an exchange-rate adjusted local wholesale price index, with exchange rates and price indexes taken from the International Financial Statistics (IFS) of the International Monetary Fund.

Real gross domestic product is measured in billions of 1990 U.S. dollars for each country. For this purpose, annual real GDP figures in local currencies were converted into dollars using the market exchange rate. These data are also from the IFS.

Skilled labor abundance is defined as the sum of occupational categories 0/1 (professional, technical, and kindred workers) and 2 (administrative workers) in employment in each country, divided by total employment. These figures are compiled from annual surveys reported in the 
Yearbook of Labor Statistics published by the International Labor Organization. In cases where some annual figures were missing, the skilled-labor ratios were taken to equal the period averages for each country. The variable SKDIFF is then simply the difference between the relative skill endowment of the parent country and that of the affiliate country.

The cost of investing in the affiliate country is a simple average of several indexes of impediments to investment, reported in the World Competitiveness Report of the World Economic Forum. ${ }^{6}$ The indexes include restrictions on ability to acquire control in a domestic company, limitations on the ability to employ foreign skilled labor, restraints on negotiating joint ventures, strict controls on hiring and firing practices, market dominance by a small number of enterprises, an absence of fair administration of justice, difficulties in acquiring local bank credit, restrictions on access to local and foreign capital markets, and inadequate protection of intellectual property. These indexes are computed on a scale from 0 to 100 , with a higher number indicating higher investment costs.

A trade cost index is taken from the same source and is defined as a measure of national protectionism, or efforts to prevent importation of competitive products. It also runs from 0 to 100, with 100 being the highest trade costs. All of these indexes are based on extensive surveys of multinational enterprises. We also incorporate a measure of distance, which is simply the number of kilometers of each country's capital city from Washington, DC. It is unclear whether this variable captures trade costs or investment costs, since both should rise with distance.

The Appendix lists the countries for which we have at least one complete yearly set of

\footnotetext{
6 Some of these data were kindly provided by staff of the United States International Trade Commission, who used them in their report on trade liberalization (USITC, 1997).
} 
observations, along with summary statistics. The final data set, after eliminating any row with missing variables, contains 509 observations. An additional 119 observations are complete except that no foreign affiliate sales are listed in the Commerce Department data. On examination, these countries in all cases are relatively poor and generally small. Thus, we conjecture that the missing observations are in fact zeros. We then perform alternative estimations using a Tobit procedure, adding these cases to the data set for a total of 628 observations.

Results for the central-case regressions, excluding and including distance, are shown in Tables 1 and 2. The regressions in Table 1 are estimated with a weighted least-squares procedure, employing a Park-Glejser correction for heteroskedasticity. The first four variables capture the relationships shown in Figures 1-3. All of the coefficients on these variables have the hypothesized signs and are highly significant. Moreover, their magnitudes are relatively insensitive to the inclusion of the distance variable in the second regression.

The next four variables involve the trade and investment cost measures. All signs are consistent with the theory, although TCJ and TCI are insignificant in the first regression. Note that adding distance, which in itself has a highly significant and negative impact on affiliate sales, markedly raises the magnitude and significance of the investment-cost variable in the host country, with a similar but smaller impact on the trade-cost variable. ${ }^{7}$ Thus, controlling for distance, the decisions of multinational enterprises in setting output levels of affiliates are responsive to perceived costs of investing in the country and the strength of import protection. This outcome is sensible given our measures of investment costs and trade costs, which are indexes of perceived

\footnotetext{
${ }^{7}$ It is not clear theoretically what the sign of the distance effect should be because distance may lead to a "substitution" effect toward investment and away from exports, but also generate a "scale" effect that decreases both trade and investment. The negative impact here is consistent with the finding of Brainard (1997).
} 
costs and protectionism developed from surveys of multinational managers. The survey questions do not ask about geographical distance, implying that the respondents do not factor it into their answers. Thus, we have conceptually distinctive measures of distance and costs, although the measures are correlated, as noted in the Appendix.

Results of the Tobit estimation are given in Table 2. Adding the cases with real sales values of zero (ie, no affiliate activity) has virtually no impact on the SUMGDP and GDPDIFSQ coefficients, but markedly increases the magnitudes of those on SKDIFF and GDPDIFF*SKDIFF, while all four variables remain highly significant. The impact on the variables incorporating differences in skilled-labor endowments is sensible because the zero-RSALES observations are overwhelmingly cases where the potential parent nation is skilled-labor-scarce and smaller than the potential affiliate nation (the United States). Excluding them from the WLS estimation in Table 1 likely biases downward the role of skilled labor. This impact is seen also in the interaction term between trade costs and squared skill differences, comparing the first columns of Tables 1 and 2. Finally, including distance in the Tobit regression has similar effects on the variables incorporating trade costs and investment costs as it did in the WLS regression.

Overall, we believe the results in Tables 1 and 2 provide strong support to the knowledgecapital model of foreign direct investment. Affiliate sales are strongly sensitive to bilateral aggregate economic activity, squared differences in GDP, differences in skilled labor endowments, and the interaction between size and endowment differences. The evidence suggests more weakly that affiliate activity depends on investment costs and trade costs in the hypothesized directions. We wish to use these results to characterize the various direct and indirect impacts more fully, which is the next task. 


\section{Interpreting the coefficients}

In this section, we interpret the magnitude of the coefficients and interpret the partial derivatives discussed above. For this purpose, we employ the coefficients from the distanceinclusive model in Table 1 and apply them to average data values from the year 1991.

First, consider increases in trade costs as measured by the index TCJ. It is clear from the estimation that trade costs increase affiliate production when countries have identical relative endowments of skilled labor $(\mathrm{SKDIFF}=0)$. This is consistent with horizontal investment. How large does the difference in relative endowments of skilled labor have to be in order to reverse the sign of the derivative, so that an increase in TCJ leads to a fall in affiliate production (vertical investment)? Recall that the variable SKDIFF is the difference between the proportion of the labor force that is skilled in the parent country minus the proportion that is skilled in the affiliate country. So a value of SKDIFF $=0.20$, for example, could occur if country $i$ has a skill ratio of 0.30 and country $\mathrm{j}$ has a skill ratio of 0.10 . Results from Table 1 support the following computation.

$$
\begin{aligned}
& \frac{\partial R S A L E S}{\partial T C J}=B 6+B 7(\text { SKDIFSQ }) \\
& =196.6-569.9 * \text { SKDIFSQ }>0 \text { iff SKDIFF }<0.587
\end{aligned}
$$

In the data, no recorded difference in skill ratios exceeded this critical value. We can therefore state the following empirical conclusion.

Result 1: An increase in the host-country's trade costs will raise production by affiliates of parent country firms in all cases. 
This result states that higher host-country trade costs always lead to more affiliate production in that country, although large differences in relative endowments weaken the result. This finding is thus roughly consistent with Figure 4, although in that diagram there are large areas in which the hostcountry trade cost has no effect.

Second, consider an increase in country i's GDP, holding total world GPD constant (i.e, country j's GPD change is the negative of country i's change). When countries have identical relative endowments, this derivative is positive with GDPDIFF $<0$, zero at GDPDIFF $=0$, and negative with GDPDIFF $>0$. With country i more skilled-labor abundant than country $\mathrm{j}$, the theory and simulations predicted that this derivative switches sign, from positive to negative, at a lower value of GDPDIFF (see Figure 2). Results from Table 1 (distance included) give us the following results.

$$
\begin{aligned}
& \frac{\partial R S A L E S}{\partial G D P D I F F}=B 2(2 * G D P D I F F)+B 4(\text { SKDIFF }) \\
& =\quad-0.0014 * 2 *(\text { GDPDIFF })-4.3 *(\mathrm{SKDIFF})
\end{aligned}
$$

An increase in a country's GDP will increase its affiliate sales abroad only if it is small and/or skilled-labor scarce. ${ }^{8}$

One interesting interpretation of these results involves the convergence in income between the United States and its trading partners, holding total "world" income constant (SUMGDP is constant). Using values of SKDIFF from the data, it turns out that the contribution of the last term in Equation (3) is small and is always dominated by the first term. Note that GDPDIFF is

\footnotetext{
8 There are 66 country pairs (i,j observations) with positive affiliate sales from $i$ to $j$ in 1991 . Fifty-nine of these have complete data for this exercise. Thirty-six of the 59 are affiliate sales of US firms in some country $\mathrm{j}$ and 23 are country i affiliate sales in the US.
} 
always positive if the US is country $i$ and negative if the US is country $j$.

Result 2: A convergence in income (GDP) between the United States and country $j$ (holding the sum of their incomes constant) increases affiliate sales in both directions.

This result is connected to the theory in Figure 6, which plots affiliate production along the SW-NE diagonal of the factor box (countries differ in size but have identical relative endowments) from Figure 1. Affiliate production by h-owned firms in $\mathrm{f}$ (see Figure 2) and f-owned firms in $\mathrm{h}$ are plotted separately in Figure 6. The larger country always has a larger share of total affiliate sales except when the countries are extremely different in size. ${ }^{9}$ Note that there are regions of relative size, ranging from 0.25 to 0.40 and from 0.60 to 0.75 , where a convergence in country size toward the center of the box increases affiliate sales in both directions. This occurs when the difference in country size is "moderately large but not too large". Our empirical results emphasize the relevance of this result.

Third, consider an increase in the skilled-labor abundance of country i relative to country $\mathrm{j}$. Our results in Table 1 indicate that this derivative is generally positive for similar countries, but its (absolute) value is reduced by a higher relative endowment difference or a larger GPD difference.

$$
\begin{aligned}
& \frac{\partial R S A L E S}{\partial S K D I F F}=B 3+B 4(\text { GDPDIFF })+B 7(2 * \text { TCJ *SKDIFF }) \\
& =31044-4.3 *(\text { GDPDIFF })-569.9 * 2 *(\text { TCJ } * \text { SKDIFF })
\end{aligned}
$$

\footnotetext{
9 When the countries are extremely different in size, all production is in the large country, most of which is by single-plant national firms headquartered in the large country. But this situation leaves the price of skilled labor low in the small country, inducing a few firms to place headquarters there. Thus, production abroad is affiliate sales of small-country firms in the large country.
} 
Large values of SKDIFF and GDPDIFF weaken the effects of an increase in skilled-labor abundance on outward affiliate sales.

Inserting values for SKDIFF, TCJ and GDPDIFF for the 1991 data, these results imply the following.

Result 3: An increase in the parent country's skilled labor abundance relative to the host country increases affiliate sales from the parent to the host except when the US is parent and the host is India, Indonesia, Republic of Korea, Malaysia, or Philippines.

These exceptions are cases where the US (the parent) is highly skilled-labor abundant relative to the host. This result connects to the theory as shown in Figure 7, which graphs affiliate sales by howned firms in country f, as country h's share of world skilled labor varies, holding each country's share of unskilled labor at one-half (i.e., this represents the cells above column "10" of Figure 2). At low levels of skilled labor, country h has no affiliate sales. These eventually become positive, but then finally fall as country $\mathrm{f}$ becomes very skilled-labor scarce. Even the modest skilled-labor requirements in plant fixed costs become too expensive in country $\mathrm{f}$ and both production and headquarters are concentrated in country h. The developing- country exceptions to the outcome in Result 3 are consistent with the right-hand end of Figure 7, where further increases in country h's skilled-labor abundance lead to a fall in affiliate sales.

As a final point, we note that the theory suggests a sharper hypothesis on the coefficient of SUMGDP than that it is simply positive. Higher total income should lead to some shifting from national firms, which are high marginal-cost suppliers to foreign markets, to horizontal multinationals, which are high fixed-cost suppliers (Markusen and Venables, 1998). In regions of parameter space in which regime shifting does not occur, affiliate production should rise in 
proportion to total world income. Overall, this suggests that affiliate sales should be elastic with respect to world income. We therefore used the results to calculate the implied elasticity of total affiliate sales (RSALES) with respect to total income (SUMGDP) for 1991 in the data. The result is an elasticity of 5.35: an increase of world real income of $1 \%$ results in an estimated $5.35 \%$ increase in affiliate sales, other things equal. This finding further supports the underlying theory.

\section{Further Econometrics}

The results presented above are from a panel data set and it is of interest to decompose them into cross-section and time-series effects. Before discussing this, we emphasize that the theoretical results apply equally well to time-series and cross-section processes. That is, the theory should correctly characterize both the time-path of the interactions between two countries and the interactions among countries in a single year. For example, as two countries grow in total GDP and become more similar in size over time, direct investment between them should grow in the manner suggested by the theory. Among a set of countries in a given year, the same bilateral relationships should apply.

One way to isolate the cross-section contribution to the results is to use single-year regressions or to average the years for each variable. We have done the latter, but the procedure generates a severe multicollinearity problem due to the bilateral nature of the data, with the United States always being one of the two countries in each data point (the same problem would occur for individual years). The resulting data set has only 63 observations.

The principal difficulty is that SUMGDP and GDPDIFSQ are highly collinear: they have a 
correlation coefficient of 0.995 in our cross section. The time-series variation in U.S. GDP is vital to identifying the separate contributions of these two variables and this information is discarded in the averaging procedure (or in the use of a single year). We can partially reduce this problem by using the non-U.S. country's GDP (NGDP) in place of SUMGDP and that country's squared GDP (GDPNSQ) in place of GDPDIFSQ (regardless of whether the United States is the source or host country). Then the U.S. GDP in each observation is blended into the constant term. Since the United States is always the larger country, the theory tells us that the coefficient on GDPN should be positive, regardless of whether country $\mathrm{N}$ is the source or host nation (catching up to the United States increases investment in both directions). The hypothesized negative coefficient on GDPNSQ is the diminishing effect of increasing country N's GDP (the theory says that eventually further increases in GDPN will reduce investment in both directions).

A second problem is that there is far less independent information than would appear with 63 observations. The variable TCI has the same value for all U.S. outward investments and TCJ and INVCJ have the same values for all investments in the United States. The three variables GDPN, GDPNSQ, and GDPDIFF*SKDIFF have the same values for U.S. investments in country $\mathrm{N}$ and country $\mathrm{N}$ investments in the United States. The variables GDPN and GDPNSQ still have a correlation of 0.93 . Despite these difficulties, we report results for the averaged cross-section in Table 3, with the distance variable included. This regression corresponds to the second one in Table 1, except that the coefficients on GDPN, GDPNSQ, and the intercept in Table 3 cannot be compared to those on SUMGDP, GDPDIFSQ, and the intercept in the former table.

Not surprisingly, the standard errors are large, given the problems just mentioned. The coefficients on TCJ, TCI, and GDPDIFF*SKDIFF are insignificant, as is the coefficient on 
TCJ*SKDIFSQ. However, only the coefficient on TCJ*SKDIFSQ has the wrong sign. Statistical significance aside, the magnitude of the coefficients for SKDIFF, and INVCJ are not much different in the two tables.

To distinguish the time-series contributions to the results we employ country fixed effects. Table 4 lists results where the equation contains a dummy variable for each country (regardless if it is the source or recipient country in a given observation) except the United States. The first regression employs WLS and the second is the related Tobit estimation. We do not report the coefficients of the country dummies, but most are significant. ${ }^{10}$

The results are qualitatively similar to those in Table 1 for the first group of four variables, except that the coefficient on SKDIFF is reduced by half. The magnitudes of the coefficients on INVCJ and TCJ are considerably smaller in Table 4 as well and both have lower significance levels. Thus, although the sign pattern is robust to the inclusion of country fixed effects, it is difficult to identify confidently the contribution of trade costs and investment costs to multinational production.

The Tobit results also show a smaller coefficient for SKDIFF with the country dummies added. The variables measuring perceived trade costs are significant in this specification in the hypothesized directions, but the investment-cost variable is not. Overall, it appears that the addition of country fixed effects does not change the results qualitatively, but a smaller role for endowment differences is predicted. ${ }^{11}$ It is noteworthy that in the Tobit specification, which

\footnotetext{
${ }^{10}$ Results are available on request. We also tried country-pair dummies but with the United States as a partner in each case this procedure could not well distinguish individual country effects.

11 Most of the countries in the sample are less skilled-labor-abundant than the United States. It may be that the country dummies are capturing some of this effect that should be correctly attributed to endowment differences, as it is in the panel and in the cross-section.
} 
incorporates many more developing countries with zero reported affiliate sales, the magnitudes and significance levels of trade costs in both host and parent countries are expanded, as are those of relative endowment differences. This result provides some support for the notion that horizontal and vertical FDI respond differently to host-country and parent-country trade protection.

\section{Summary}

The knowledge-capital approach to the multinational enterprise as outlined in this paper is operational and yields clear, testable hypotheses. It this sense, it is more useful that some other theories of FDI, such as the "transactions cost" approach to multinational enterprises.

In this paper, we test hypotheses regarding the importance of multinational activity between countries as a function of certain characteristics of those countries, particularly size, size differences, relative endowment differences, trade and investment costs, and certain interactions among these variables as predicted by the theory. In our view, the model fits well and gives considerable support to the theory. The panel estimates in Tables 1 and 2 yield correct signs and strong statistical significance (when distance is included) for the central variables SUMGPD, GDPDIFSQ, SKDIFF, GDPDIFF*SKDIFF, INVCJ, and TCJ. Other variables (TCI and TCJ*SKDIFSQ) have correct signs but display weak statistical significance. Our efforts to separate the panel results into cross-section and time-series impacts are made problematic by multicollinearity in the cross-section data. Because of the bilateral nature of these data, the time-series variation in the U.S. observations is critical to identification of the contributions of several variables. Estimation with 
country fixed effects produced results consistent with the panel approach. ${ }^{12}$

According to our findings, outward investment from a source country to affiliates in a host country is increasing in the sum of their economic sizes, their similarity in size, the relative skilled-labor abundance of the parent nation, and the interaction between size and relative endowment differences. Some of these findings are consistent with earlier results, particularly those of Brainard (1993) and Ekholm (1997b). But the precise formulations here are different and closely tied to one particular model. This model allows for simultaneous horizontal and vertical motives for direct investment and emphasizes certain interactions, such as that between size and endowment differences. We should also note that the theoretical model fully endogenizes trade flows in its calculations, allowing direct predictions on affiliate sales without requiring us to worry about questions of trade versus investment. Trade, like factor and commodity prices, is endogenous in generating the predictions of the model.

Subsequent to the estimation, we interpreted the estimates in the language of comparativestatics questions about the world economy. Results indicate first that increases in host-country trade costs will increase inward affiliate production, second that a convergence in country size between the US and country i will increase affiliate sales in both directions, and third that an increase in a country's skilled-labor abundance will increase outward affiliate sales for almost all country pairs.

In summary, we are enthusiastic about the results, and hope that the model will therefore prove useful in future policy analysis.

\footnotetext{
${ }^{12}$ For comparison purposes, we ran a simple gravity equation on the panel data set, with log real affiliate sales regressed on log real GDP in host and parent countries and log distance. The gravity equation displayed a considerably lower adjusted $R^{2}(0.46)$ than the panel equation based on the theoretical model $(0.60)$.
} 


\section{REFERENCES}

Aitken, Brian, Ann Harrison, and Robert E. Lipsey (1995), "Wages and Foreign Ownership: A Comparative Study of Mexico, Venezuela, and the United States", NBER working paper 5102.

Blomstrom, Magnus, Gunnar Fors, and Robert E. Lipsey, "Foreign Direct Investment and Employment: Home Country Experience in the United States and Sweden", NBER working paper 6205, 1997.

Brainard, S. Lael, "A Simple Theory of Multinational Corporations and Trade with a Trade-off between Proximity and Concentration", NBER Working Paper No. 4269, February 1993a.

Brainard, S. Lael, "An Empirical Assessment of the Factor Proportions Explanation of Multinationals Sales", NBER Working Paper No. 4580, December 1993 b.

Brainard, S. Lael, "An Empirical Assessment of the Proximity-Concentration Tradeoff between Multinational Sales and Trade", American Economic Review, 1997, 87, 520-544.

Braunerhjelm, Pontus and Karolina Ekholm (editors), The Geography of Multinational Firms. Boston: Kluwer Academic Publishers. 1998.

Caves, Richard E., Multinational Enterprise and Economic Analysis. London: Cambridge University Press. 1996, second edition.

Ekhlom, Karolina, Multinational Production and Trade in Technological Knowledge, Lund Economic Studies, number 58, 1995.

Ekholm, Karolina, "Headquarter Services and Revealed Factor Abundance", Review of International Economics, 1997a.

Ekholm, Karolina, "Factor Endowments and the Pattern of Affiliate Production by Multinational Enterprises", CREDIT working paper no. 97/19, University of Nottingham, 1997b.

Ekholm, Karolina, "Proximity Advantages, Scale Economies, and the Location of Production", in Braunerhjelm and Ekholm (editors), The Geography of Multinational Firms. Boston: Kluwer Academic Publishers. 1998.

Feenstra, Robert C. and Gordon H. Hanson, "Foreign Direct Investment and Relative Wages: Evidence from Mexico's Maquiladoras", Journal of International Economics 1997, 42, 371-393.

Helpman, Elhanan, "A Simple Theory of Trade with Multinational Corporations", Journal of 
Political Economy, 1984, 92, 451-471.

Helpman, Elhanan, "Multinational Corporations and Trade Structure", Review of Economic Studies, 1985, 52, 443-458.

Horstmann, Ignatius J. and James R. Markusen, "Strategic Investments and the Development of Multinationals," International Economic Review, 1987, 28, 109-121.

Horstmann, Ignatius J. and James R. Markusen, "Endogenous Market Structures in International Trade," Journal of International Economics, 1992, 32, 109-129.

Lipsey, Robert E., Magnus Blomstrom and Eric Ramstetter, "Internationalized Production in World Output", NBER working paper 5385, 1995.

Markusen, James R., "Multinationals, Multi-Plant Economies, and the Gains from Trade", Journal of International Economics 1984, 16, 205-226.

Markusen, James R., "The Boundaries of Multinational Firms and the Theory of International Trade", Journal of Economic Perspectives 1995, 9, 169-189.

Markusen, James R., "Trade versus Investment Liberalization", NBER working paper 6231, 1997.

Markusen, James R. and Anthony J. Venables, "The Increased Importance of Multinationals in North American Economic Relationships: A Convergence Hypothesis", in Canzoneri, Matthew W.,Wilfred J. Ethier, and Vitoria Grilli (editors), The New Transatlantic Economy, London: Cambridge University Press, 1996.

Markusen, James R. and Anthony J. Venables, "The Role of Multinational Firms in the Wage-Gap Debate", Review of International Economics 1997, 5, 435-451.

Markusen, James R. and Anthony J. Venables, "Multinational Firms and the New Trade Theory", Journal of International Economics 1998 forthcoming.

Markusen, James R., Anthony J. Venables, Denise Eby Konan, and Kevin Zhang, "A Unified Treatment of Horizontal Direct Investment, Vertical Direct Investment, and the Pattern of Trade in Goods and Services", NBER working paper 5696, 1996.

Rutherford, Thomas F., "Applied General-Equilibrium Modelling with MPS/GE as a GAMS Subsystem" 1995a.

Rutherford, Thomas F., "Extensions of GAMS for Complementarity Problems Arising in Applied Economics", Journal of Economic Dynamics and Control 1995b. 
Slaughter, Matthew J., "Multinational Corporations, Outsourcing, and American Relative Wage Divergence", Journal of International Economics 1999 forthcoming.

UNCTAD, World Investment Report, 1993. 
Table 1. Results for Basic Model of Real Sales Volume of Affiliates: WLS Estimation

\begin{tabular}{|c|c|c|c|c|}
\hline Variable & $\begin{array}{l}\text { Parameter } \\
\text { Estimate }\end{array}$ & $\begin{array}{l}\text { Sign as } \\
\text { Predicted? }\end{array}$ & $\begin{array}{l}\text { Parameter } \\
\text { Estimate }\end{array}$ & $\begin{array}{l}\text { Sign as } \\
\text { Predicted? }\end{array}$ \\
\hline SUMGDP & $\begin{array}{r}15.80 \\
(11.20)\end{array}$ & $\begin{array}{l}\text { Yes } \\
(0.0001)\end{array}$ & $\begin{array}{r}13.92 \\
(9.80)\end{array}$ & $\begin{array}{l}\text { Yes } \\
(0.0001)\end{array}$ \\
\hline GDPDIFSQ & $\begin{array}{r}-0.0015 \\
(-9.45)\end{array}$ & $\begin{array}{l}\text { Yes } \\
(0.0001)\end{array}$ & $\begin{array}{r}-0.0014 \\
(-8.90)\end{array}$ & $\begin{array}{l}\text { Yes } \\
(0.0001)\end{array}$ \\
\hline SKDIFF & $\begin{array}{l}24114 \\
(3.16)\end{array}$ & $\begin{array}{l}\text { Yes } \\
(0.0017)\end{array}$ & $\begin{array}{l}31044 \\
(4.01)\end{array}$ & $\begin{array}{l}\text { Yes } \\
(0.0001)\end{array}$ \\
\hline GDPDIFF*SKDIFF & $\begin{array}{r}-6.20 \\
(-3.17)\end{array}$ & $\begin{array}{l}\text { Yes } \\
(0.0016)\end{array}$ & $\begin{array}{r}-4.27 \\
(-2.12)\end{array}$ & $\begin{array}{l}\text { Yes } \\
(0.035)\end{array}$ \\
\hline INVCJ & $\begin{array}{l}-192.5 \\
(-1.79)\end{array}$ & $\begin{array}{l}\text { Yes } \\
(0.075)\end{array}$ & $\begin{array}{l}-455.6 \\
(-3.92)\end{array}$ & $\begin{array}{l}\text { Yes } \\
(0.0001)\end{array}$ \\
\hline TCJ & $\begin{array}{r}108.5 \\
(1.29)\end{array}$ & $\begin{array}{l}\text { Yes } \\
(0.199)\end{array}$ & $\begin{array}{l}196.6 \\
(2.20)\end{array}$ & $\begin{array}{l}\text { Yes } \\
(0.029)\end{array}$ \\
\hline TCJ*SKDIFSQ & $\begin{array}{r}-2591 \\
(-1.93)\end{array}$ & $\begin{array}{l}\text { Yes } \\
(0.054)\end{array}$ & $\begin{array}{l}-569.9 \\
(-0.41)\end{array}$ & $\begin{array}{l}\text { Yes } \\
(0.683)\end{array}$ \\
\hline TCI & $\begin{array}{r}-72.2 \\
(-0.89)\end{array}$ & $\begin{array}{l}\text { Yes } \\
(0.377)\end{array}$ & $\begin{array}{r}-93.3 \\
(-1.14)\end{array}$ & $\begin{array}{l}\text { Yes } \\
(0.256)\end{array}$ \\
\hline DIST & & & $\begin{array}{r}-1.34 \\
(-6.63)\end{array}$ & $\begin{array}{l}? \\
(0.0001)\end{array}$ \\
\hline INTERCEPT & $\begin{array}{l}-29889 \\
(-2.47)\end{array}$ & $(0.014)$ & $\begin{array}{r}-5381 \\
(-0.42)\end{array}$ & $(0.676)$ \\
\hline $\begin{array}{l}\text { Observations } \\
\text { Adjusted } \mathrm{R}^{2}\end{array}$ & $\begin{array}{r}509 \\
0.56\end{array}$ & & $\begin{array}{r}509 \\
0.60\end{array}$ & \\
\hline
\end{tabular}

Notes: Both models are adjusted for heteroskedasticity using the Park-Glejser method. Figures in parentheses below coefficients are $t$ statistics. Marginal significance levels of the coefficients are indicated in parentheses below sign predictions. 
Table 2. Results for Basic Model of Real Sales Volume of Affiliates: Tobit Estimation

\begin{tabular}{|c|c|c|c|c|}
\hline Variable & $\begin{array}{l}\text { Parameter } \\
\text { Estimate }\end{array}$ & $\begin{array}{l}\text { Sign as } \\
\text { Predicted? }\end{array}$ & $\begin{array}{l}\text { Parameter } \\
\text { Estimate }\end{array}$ & $\begin{array}{l}\text { Sign as } \\
\text { Predicted? }\end{array}$ \\
\hline SUMGDP & $\begin{array}{r}15.61 \\
(104.3)\end{array}$ & $\begin{array}{l}\text { Yes } \\
(0.0001)\end{array}$ & $\begin{array}{r}15.04 \\
(105.5)\end{array}$ & $\begin{array}{l}\text { Yes } \\
(0.0001)\end{array}$ \\
\hline GDPDIFSQ & $\begin{array}{r}-0.0010 \\
(32.14)\end{array}$ & $\begin{array}{l}\text { Yes } \\
(0.0001)\end{array}$ & $\begin{array}{r}-0.0010 \\
(34.67)\end{array}$ & $\begin{array}{l}\text { Yes } \\
(0.0001)\end{array}$ \\
\hline SKDIFF & $\begin{array}{r}55033 \\
(32.14)\end{array}$ & $\begin{array}{l}\text { Yes } \\
(0.0001)\end{array}$ & $\begin{array}{r}61700 \\
(52.98)\end{array}$ & $\begin{array}{l}\text { Yes } \\
(0.0001)\end{array}$ \\
\hline GDPDIFF*SKDIFF & $\begin{array}{r}-12.78 \\
(27.69)\end{array}$ & $\begin{array}{l}\text { Yes } \\
(0.0001)\end{array}$ & $\begin{array}{r}-10.20 \\
(18.81)\end{array}$ & $\begin{array}{l}\text { Yes } \\
(0.0001)\end{array}$ \\
\hline INVCJ & $\begin{array}{r}-156.0 \\
(1.27)\end{array}$ & $\begin{array}{l}\text { Yes } \\
(0.260)\end{array}$ & $\begin{array}{l}-378.6 \\
(7.98)\end{array}$ & $\begin{array}{l}\text { Yes } \\
(0.005)\end{array}$ \\
\hline TCJ & $\begin{array}{l}83.93 \\
(0.61)\end{array}$ & $\begin{array}{l}\text { Yes } \\
(0.435)\end{array}$ & $\begin{array}{l}156.2 \\
(2.28)\end{array}$ & $\begin{array}{l}\text { Yes } \\
(0.131)\end{array}$ \\
\hline TCJ*SKDIFSQ & $\begin{array}{l}-3573 \\
(4.39)\end{array}$ & $\begin{array}{l}\text { Yes } \\
(0.036)\end{array}$ & $\begin{array}{l}-1264 \\
(0.57)\end{array}$ & $\begin{array}{l}\text { Yes } \\
(0.573)\end{array}$ \\
\hline TCI & $\begin{array}{l}-137.6 \\
(2.52)\end{array}$ & $\begin{array}{l}\text { Yes } \\
(0.113)\end{array}$ & $\begin{array}{r}-122.0 \\
(2.13)\end{array}$ & $\begin{array}{l}\text { Yes } \\
(0.144)\end{array}$ \\
\hline DIST & & & $\begin{array}{r}-1.48 \\
(41.92)\end{array}$ & $\begin{array}{l}? \\
(0.0001)\end{array}$ \\
\hline INTERCEPT & $\begin{array}{r}-40967 \\
(7.57)\end{array}$ & $(0.006)$ & $\begin{array}{r}-23282 \\
(2.59)\end{array}$ & $(0.108)$ \\
\hline $\begin{array}{l}\text { Observations } \\
\text { Log-Likelihood }\end{array}$ & $\begin{array}{r}628 \\
-5775\end{array}$ & & $\begin{array}{r}628 \\
-5755\end{array}$ & \\
\hline
\end{tabular}

Notes: Figures in parentheses below coefficients are Chi-square statistics. Marginal significance levels of the coefficients are indicated in parentheses below sign predictions. 
Table 3. Cross-Section Estimation of Basic Model, Including Distance

\begin{tabular}{|c|c|c|c|c|}
\hline \multirow[t]{2}{*}{ Variable } & WLS & \multirow{2}{*}{$\begin{array}{l}\text { Sign as } \\
\text { Predicted? }\end{array}$} & \multirow{2}{*}{ Estimate $^{\text {Tobit }}$} & \multirow{2}{*}{$\begin{array}{l}\text { Sign as } \\
\text { Predicted? }\end{array}$} \\
\hline & & & & \\
\hline GDPN & $\begin{array}{l}65.51 \\
(5.74)\end{array}$ & $\begin{array}{l}\text { Yes } \\
(0.0001)\end{array}$ & $\begin{array}{l}66.38 \\
(46.7)\end{array}$ & $\begin{array}{l}\text { Yes } \\
(0.0001)\end{array}$ \\
\hline GDPNSQ & $\begin{array}{l}-0.018 \\
(-3.72)\end{array}$ & $\begin{array}{l}\text { Yes } \\
(0.0001)\end{array}$ & $\begin{array}{r}-0.018 \\
(24.1)\end{array}$ & $\begin{array}{l}\text { Yes } \\
(0.0001)\end{array}$ \\
\hline SKDIFF & $\begin{array}{l}27176 \\
(1.29)\end{array}$ & $\begin{array}{l}\text { Yes } \\
(0.204)\end{array}$ & $\begin{array}{l}49834 \\
(5.17)\end{array}$ & $\begin{array}{l}\text { Yes } \\
(0.023)\end{array}$ \\
\hline GDPDIFF*SKDIFF & $\begin{array}{r}-2.41 \\
(-0.39)\end{array}$ & $\begin{array}{l}\text { Yes } \\
(0.702)\end{array}$ & $\begin{array}{c}-8.42 \\
(1.65)\end{array}$ & $\begin{array}{l}\text { Yes } \\
(0.199)\end{array}$ \\
\hline INVCJ & $\begin{array}{l}-462.3 \\
(-1.23)\end{array}$ & $\begin{array}{l}\text { Yes } \\
(0.223)\end{array}$ & $\begin{array}{r}-526.5 \\
(1.83)\end{array}$ & $\begin{array}{l}\text { Yes } \\
(0.176)\end{array}$ \\
\hline TCJ & $\begin{array}{r}4.11 \\
(0.01)\end{array}$ & $\begin{array}{l}\text { Yes } \\
(0.990)\end{array}$ & $\begin{array}{r}-48.5 \\
(0.02)\end{array}$ & $\begin{array}{l}\text { No } \\
(0.891)\end{array}$ \\
\hline TCJ*SKDIFSQ & $\begin{array}{r}1085 \\
(0.24)\end{array}$ & $\begin{array}{l}\text { No } \\
(0.812)\end{array}$ & $\begin{array}{r}2375 \\
(0.26)\end{array}$ & $\begin{array}{l}\text { No } \\
(0.616)\end{array}$ \\
\hline TCI & $\begin{array}{l}-125.5 \\
(-0.54)\end{array}$ & $\begin{array}{l}\text { Yes } \\
(0.595)\end{array}$ & $\begin{array}{l}-95.2 \\
(0.16)\end{array}$ & $\begin{array}{l}\text { Yes } \\
(0.689)\end{array}$ \\
\hline DIST & $\begin{array}{r}-0.55 \\
(-1.02)\end{array}$ & $\begin{array}{l}? \\
(0.314)\end{array}$ & $\begin{array}{r}-0.65 \\
(1.29)\end{array}$ & $\begin{array}{l}? \\
(0.256)\end{array}$ \\
\hline INTERCEPT & $\begin{array}{l}21861 \\
(1.54)\end{array}$ & $(0.130)$ & $\begin{array}{l}25862 \\
(3.29)\end{array}$ & $(0.070)$ \\
\hline
\end{tabular}

Observations $\quad 63$

Adjusted $\mathrm{R}^{2} \quad 0.60$

70

Log-Likelihood $\quad-687.0$

Notes: Model uses average observations for each country pair. WLS equation is adjusted for heteroskedasticity using the Park-Glejser method. Figures in parentheses below coefficients are t- statistics for the WLS equation and Chi-square statistics for the Tobit equation. Marginal significance levels of the coefficients are indicated in parentheses below sign predictions. 
Table 4. Fixed-Effects Estimation of Basic Model, Including Distance

\begin{tabular}{|c|c|c|c|c|}
\hline Variable & $\begin{array}{l}\text { WLS } \\
\text { Estimate }\end{array}$ & $\begin{array}{l}\text { Sign as } \\
\text { Predicted? }\end{array}$ & $\begin{array}{l}\text { Tobit } \\
\text { Estimate }\end{array}$ & $\begin{array}{l}\text { Sign as } \\
\text { Predicted? }\end{array}$ \\
\hline SUMGDP & $\begin{array}{l}13.72 \\
(13.6)\end{array}$ & $\begin{array}{l}\text { Yes } \\
(0.0001)\end{array}$ & $\begin{array}{r}16.57 \\
(304.2)\end{array}$ & $\begin{array}{l}\text { Yes } \\
(0.0001)\end{array}$ \\
\hline GDPDIFSQ & $\begin{array}{r}-0.0011 \\
(-9.81)\end{array}$ & $\begin{array}{l}\text { Yes } \\
(0.0001)\end{array}$ & $\begin{array}{r}-0.0009 \\
(64.2)\end{array}$ & $\begin{array}{l}\text { Yes } \\
(0.0001)\end{array}$ \\
\hline SKDIFF & $\begin{array}{l}15042 \\
(1.34)\end{array}$ & $\begin{array}{l}\text { Yes } \\
(0.181)\end{array}$ & $\begin{array}{l}29366 \\
(5.69)\end{array}$ & $\begin{array}{l}\text { Yes } \\
(0.017)\end{array}$ \\
\hline GDPDIFF*SKDIFF & $\begin{array}{r}-4.44 \\
(-2.09)\end{array}$ & $\begin{array}{l}\text { Yes } \\
(0.037)\end{array}$ & $\begin{array}{r}-7.71 \\
(10.4)\end{array}$ & $\begin{array}{l}\text { Yes } \\
(0.0013)\end{array}$ \\
\hline INVCJ & $\begin{array}{l}-173.2 \\
(-1.52)\end{array}$ & $\begin{array}{l}\text { Yes } \\
(0.129)\end{array}$ & $\begin{array}{l}-41.25 \\
(0.10)\end{array}$ & $\begin{array}{l}\text { Yes } \\
(0.752)\end{array}$ \\
\hline TCJ & $\begin{array}{l}69.36 \\
(1.02)\end{array}$ & $\begin{array}{l}\text { Yes } \\
(0.310)\end{array}$ & $\begin{array}{l}144.0 \\
(3.71)\end{array}$ & $\begin{array}{l}\text { Yes } \\
(0.054)\end{array}$ \\
\hline TCJ*SKDIFSQ & $\begin{array}{l}-811.6 \\
(-0.57)\end{array}$ & $\begin{array}{l}\text { Yes } \\
(0.572)\end{array}$ & $\begin{array}{l}-2273 \\
(2.22)\end{array}$ & $\begin{array}{l}\text { Yes } \\
(0.137)\end{array}$ \\
\hline TCI & $\begin{array}{r}-75.5 \\
(-1.60)\end{array}$ & $\begin{array}{l}\text { Yes } \\
(0.111)\end{array}$ & $\begin{array}{l}-112.6 \\
(5.89)\end{array}$ & $\begin{array}{l}\text { Yes } \\
(0.015)\end{array}$ \\
\hline DIST & $\begin{array}{l}-0.872 \\
(-4.95)\end{array}$ & $(0.0001)$ & $\begin{array}{r}-0.77 \\
(18.3)\end{array}$ & $\begin{array}{l}? \\
(0.0001)\end{array}$ \\
\hline INTERCEPT & $\begin{array}{c}-24552 \\
(-2.57)\end{array}$ & $(0.011)$ & $\begin{array}{r}-53341 \\
(27.5)\end{array}$ & $(0.0001)$ \\
\hline $\begin{array}{l}\text { Observations } \\
\text { Adjusted } \mathrm{R}^{2} \\
\text { Log-Likelihood }\end{array}$ & $\begin{array}{r}509 \\
0.87\end{array}$ & & $\begin{array}{r}628 \\
-5436\end{array}$ & \\
\hline
\end{tabular}

Notes: Figures in parentheses below coefficients are $t$ statistics for the WLS equation and Chi-square statistics for the Tobit equation. Marginal significance levels of the coefficients are indicated in parentheses below sign predictions. 
DATA APPENDIX: Countries plus the US (Figures for 1990)

COUNTRIES (countries for which at least one year is included)

$\begin{array}{lll}\text { Argentina } & \text { Greece } & \text { New Zealand } \\ \text { Australia } & \text { Hong Kong } & \text { Norway } \\ \text { Austria } & \text { India } & \text { Panama } \\ \text { Belgium } & \text { Indonesia } & \text { Philippines } \\ \text { Brazil } & \text { Ireland } & \text { Portugal } \\ \text { Canada } & \text { Israel } & \text { Singapore } \\ \text { Chile } & \text { Italy } & \text { Spain } \\ \text { Colombia } & \text { Japan } & \text { Sweden } \\ \text { Denmark } & \text { Korea } & \text { Switzerland } \\ \text { Finland } & \text { Malaysia } & \text { Turkey } \\ \text { France } & \text { Mexico } & \text { United Kingdom } \\ \text { Germany } & \text { Netherlands } & \text { Venezuela }\end{array}$

Note: *German data are for West Germany before unification and for an estimate of Western Germany since unification.

$\underline{\text { SUMMARY STATISTICS (basic sample; } \mathrm{n}=513 \text { ) }}$

$\begin{array}{lllll}\text { Variable } & \text { Mean } & \text { Std. Dev. } & \text { Minimum } & \text { Maximum } \\ \text { RSALES } & 15670 & 24316 & 0 & 120070 \\ \text { SUMGDP } & 6125 & 675 & 5210 & 9328 \\ \text { GDPDIFF } & 1146 & 5219 & -6145 & 6145 \\ \text { GDPDIFSQ } & 2.8 \mathrm{e} 7 & 0.6 \mathrm{e} 7 & 0.7 \mathrm{e} 7 & 3.8 \mathrm{e} 7 \\ \text { SKDIFF } & 0.034 & 0.012 & -0.277 & 0.277 \\ \text { SKDIFSQ } & 0.016 & 0.017 & 5.7 \mathrm{e}-7 & 0.077 \\ \text { INVCJ } & 34.00 & 10.59 & 15.30 & 79.43 \\ \text { TCJ } & 33.62 & 12.05 & 6.00 & 85.08 \\ \text { TCI } & 31.74 & 8.61 & 6.00 & 74.34 \\ \text { DIST } & 8266 & 3875 & 734 & 16370\end{array}$

CORRELATION MATRIX (basic sample; $\mathrm{n}=513$ )

\begin{tabular}{|c|c|c|c|c|c|c|c|c|c|c|}
\hline & (1) & (2) & (3) & (4) & (5) & (6) & (7) & (8) & (9) & (10) \\
\hline 1. RSALES & 1.00 & & & & & & & & & \\
\hline 2. SUMGDP & 0.53 & 1.00 & & & & & & & & \\
\hline 3. GDPDIFF & 0.01 & -0.12 & 1.00 & & & & & & & \\
\hline 4. GDPDIFSQ & -0.52 & -0.60 & 0.07 & 1.00 & & & & & & \\
\hline 5. SKDIFF & -0.10 & -0.14 & 0.70 & 0.11 & 1.00 & & & & & \\
\hline 6. SKDIFSQ & -0.29 & -0.07 & 0.20 & 0.12 & 0.33 & 1.00 & & & & \\
\hline 7. INVCJ & -0.19 & -0.18 & 0.57 & -0.02 & 0.63 & 0.46 & 1.00 & & & \\
\hline 8. TCJ & -0.10 & -0.08 & 0.12 & -0.12 & 0.27 & 0.33 & 0.65 & 1.00 & & \\
\hline 9. TCI & -0.02 & 0.03 & -0.05 & -0.14 & -0.13 & 0.12 & 0.01 & 0.08 & 1.00 & \\
\hline 10. DIST & -0.36 & -0.06 & 0.07 & 0.12 & 0.13 & 0.37 & 0.06 & 0.18 & 0.03 & 1.00 \\
\hline
\end{tabular}


Figure 1: Volume of Affliate Production: $25 \%$ trade costs

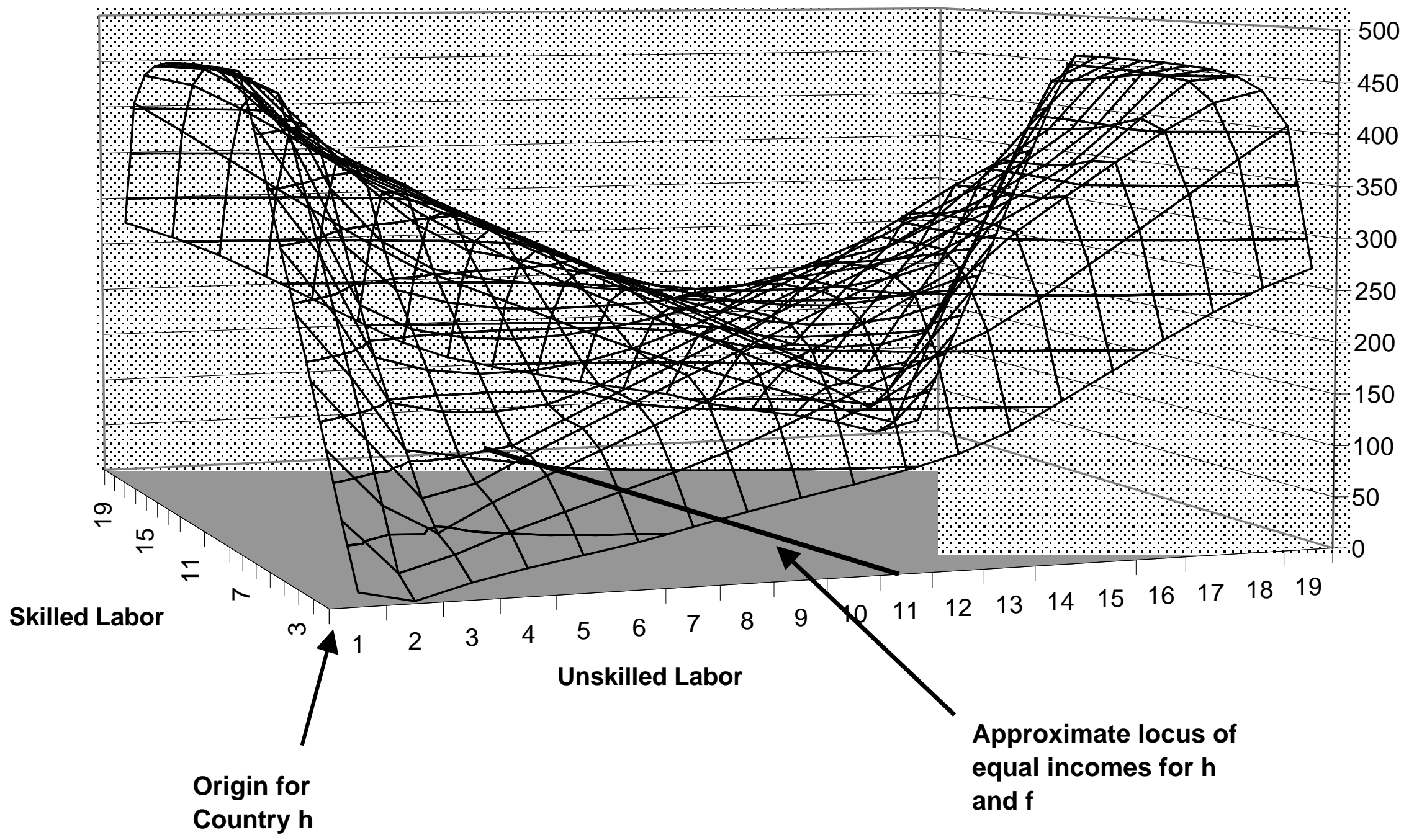


Figure 2: Affiliate Production by h-owned plants in country $f$

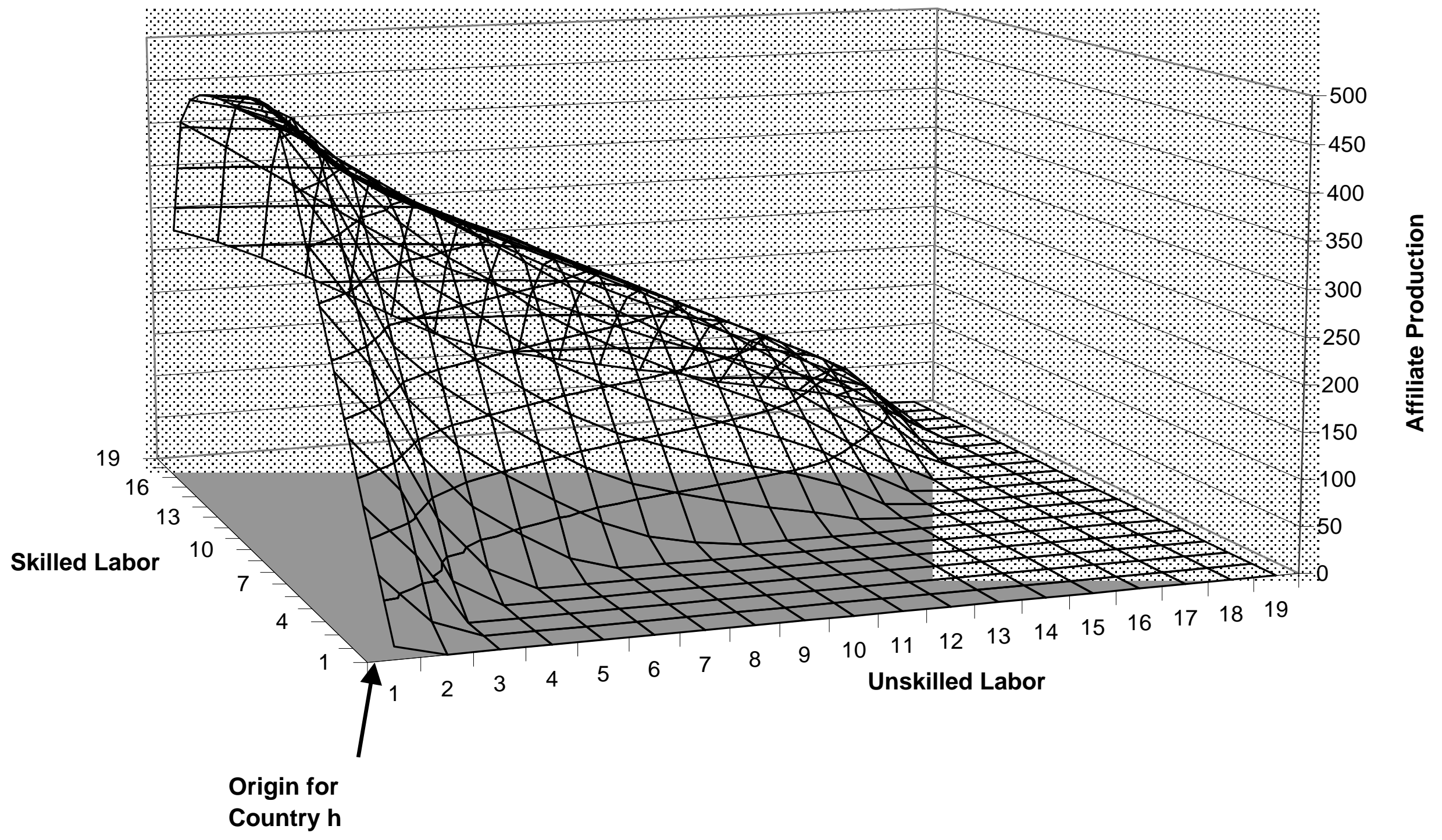


Figure 3: Change in Affiliate Production, h plants in f: $25 \%$ trade costs minus $5 \%$ trade costs in both directions

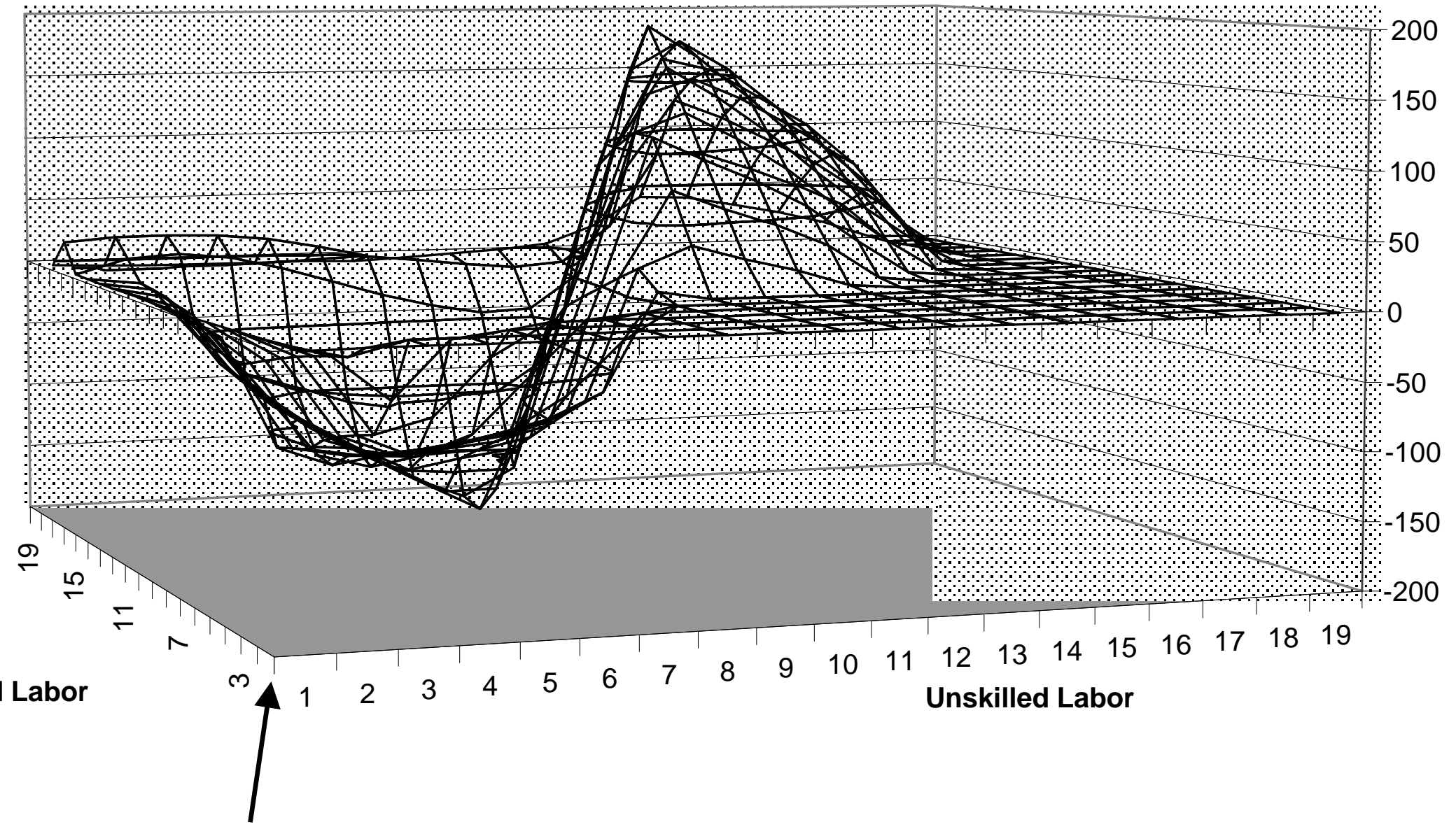

Oriigin for Country h 
Figure 4: Change in Affiliate Production by $h$ firms in f: increase in f's trade costs

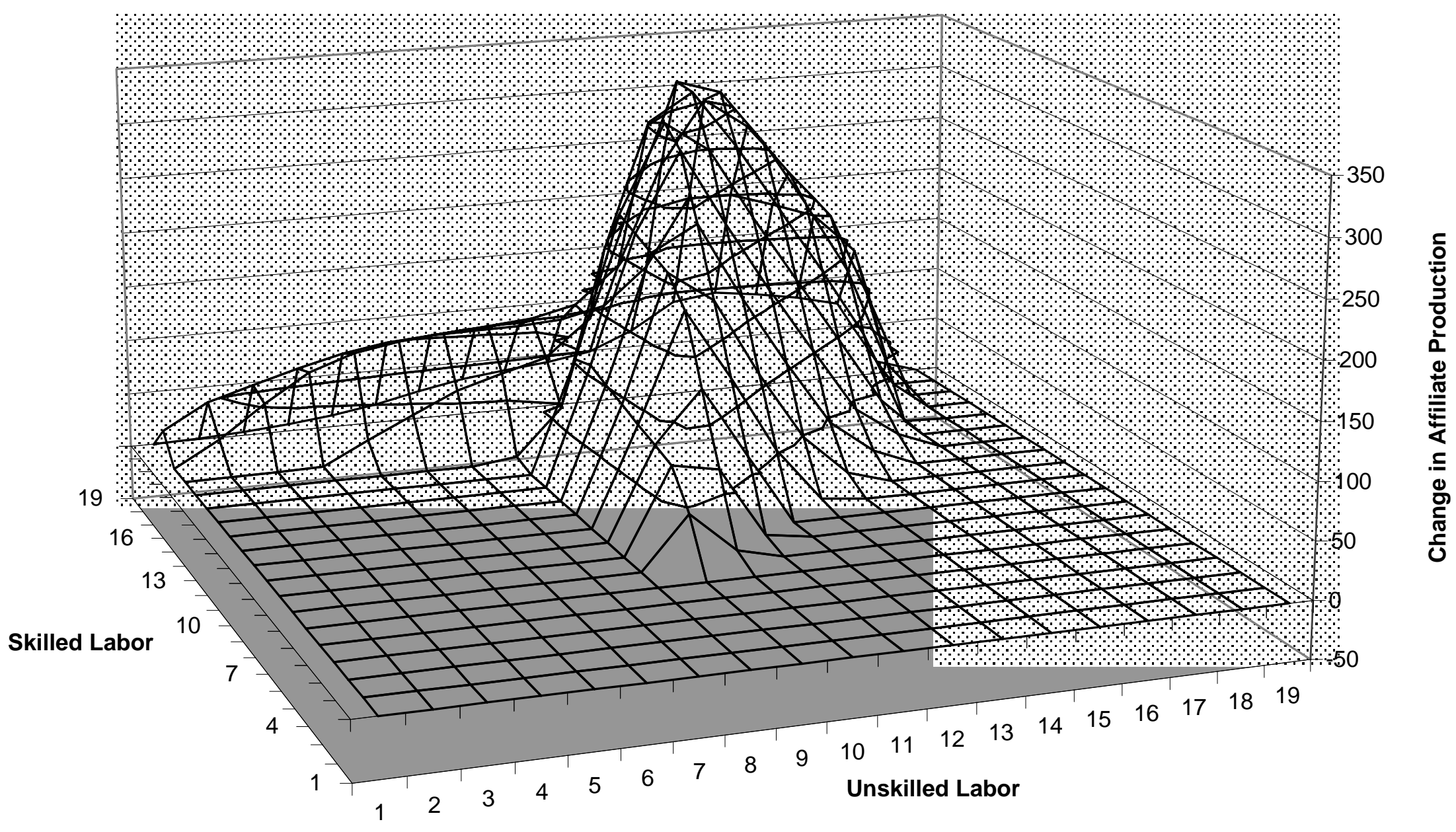


Figure 5: Change in Affiliate Production by $h$ firms in f: increase in $h$ 's trade cost

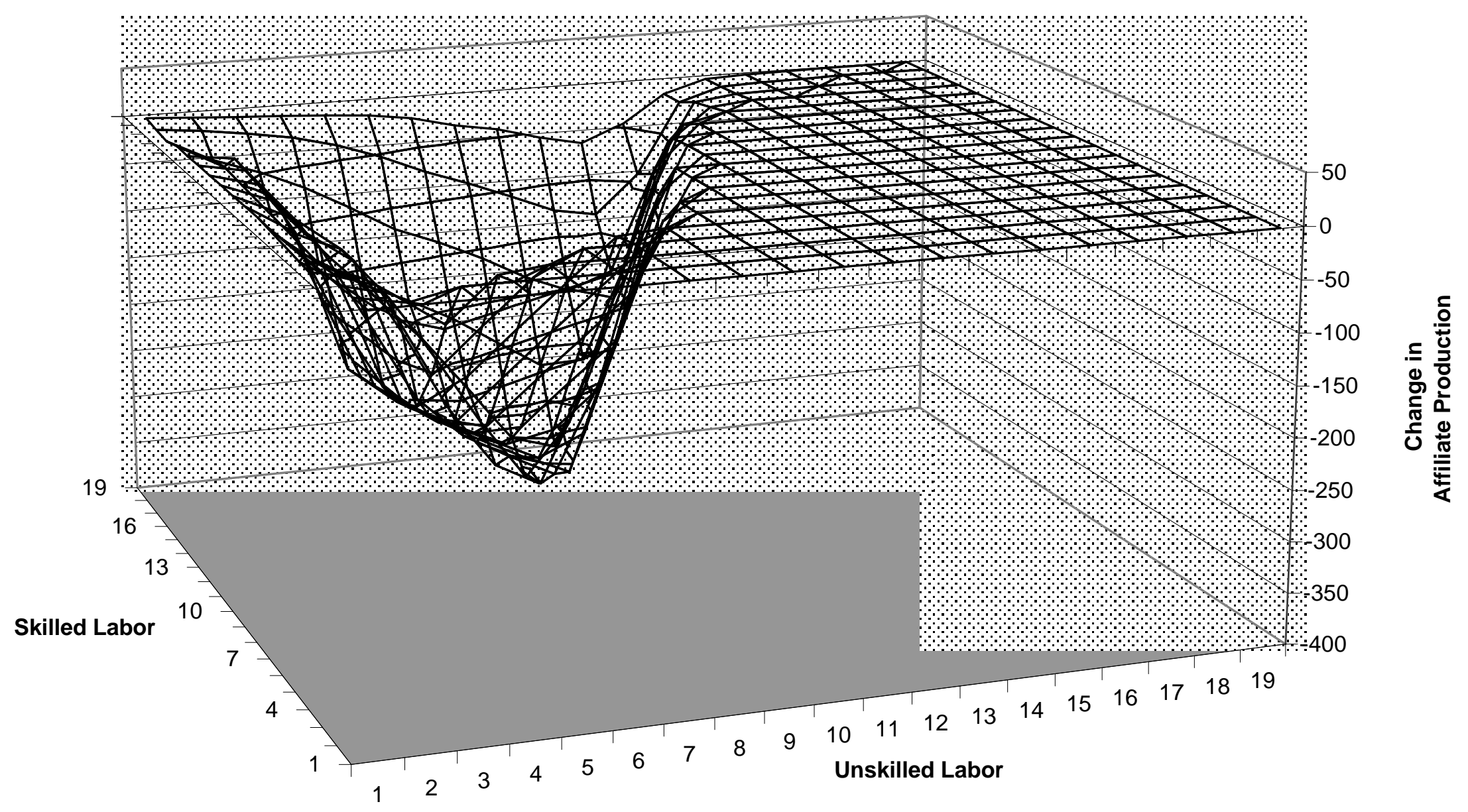



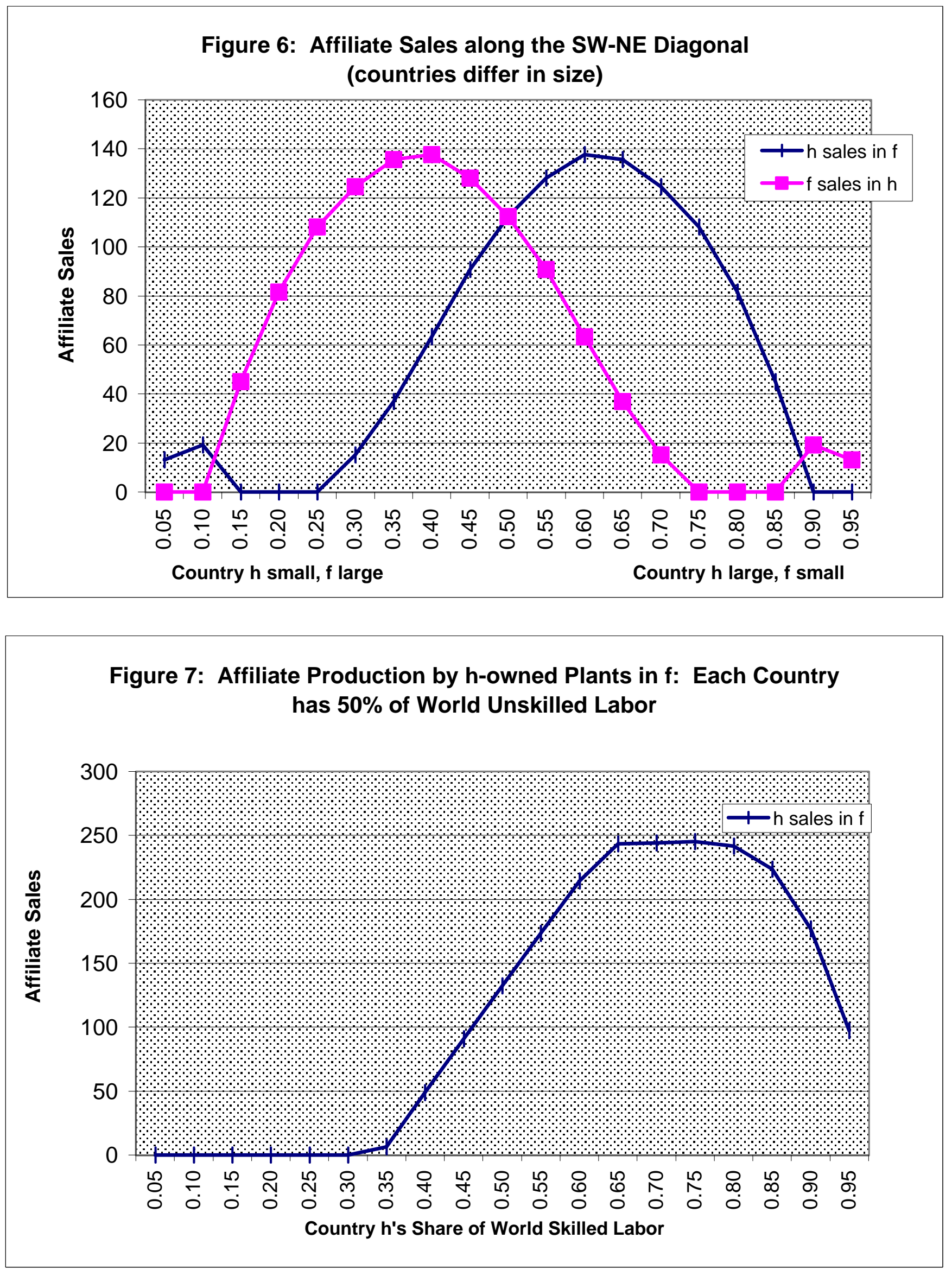
Figure 6: Affiliate Sales along the SW-NE Diagonal (countries differ in size)

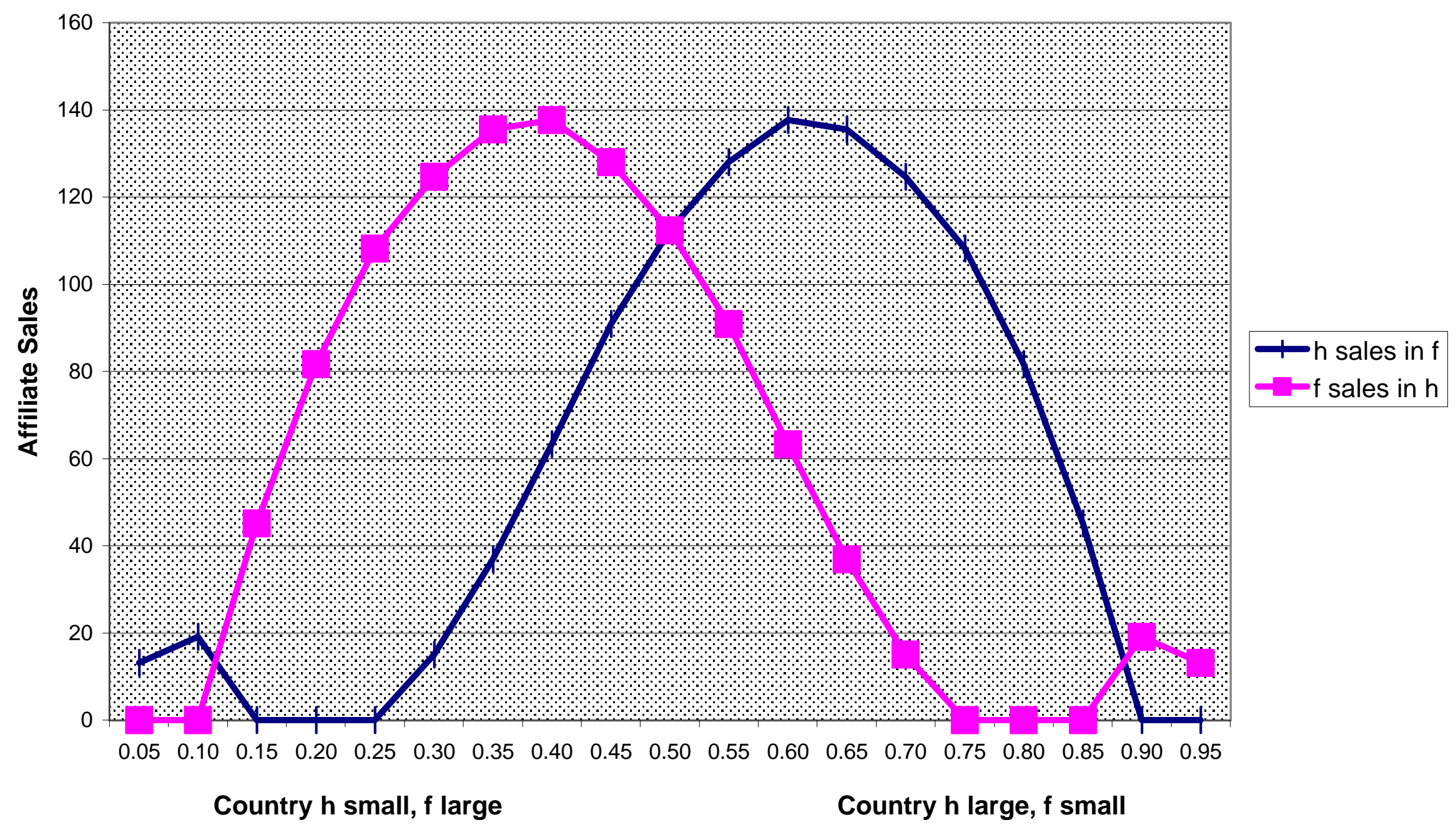

